\title{
ACTIVITIES OF UKRAINIAN COMMUNITY IN LITHUANIA
}

\author{
Olena Myroniuk \\ Postgraduate Student, Taras Shevchenko National University of Kyiv, Ukraine \\ e-mail: olenamyroniukk@gmail.com,orcid.org/0000-0003-3854-6642
}

\section{Summary}

The study is devoted to a comprehensive analysis of the Ukrainian diaspora's life in Lithuania. The Ukrainian community in this country has deep historical roots, but as in other countries of the former Soviet Union, it became more active in the late 1980s. From that time community organizations began to be formed, and become important centers of diaspora. They conduct powerful cultural-educational work. They have been spreading and popularizing our cultural traditions for quite some time. Ethnic Ukrainians constantly help their homeland and maintain a positive image of Ukraine in the world. It should also be noted that Ukrainian communities in Lithuania actively influence the transparent coverage of events in Ukraine. But Ukrainians in Lithuania are quickly assimilated and lose their identity. One of the reasons for this is that in the Republic of Lithuania after the restoration of independence, almost all Ukrainians received the citizenship of this state, in contrast to other Baltic countries. Also, the integration of newly arrived Ukrainians into the previously larger Russian community in the country. And according to the latest data, there is a much larger influx of Ukrainians over the last few years, even compared to the Russians. This gives hope that the development of the Ukrainian community will not be pretended. Currently, there is no single research that would compare the life of the Ukrainian community in Lithuania in the modern period. Thus, the systematization and analysis of information about the activities of the Ukrainian community in Lithuania are incredibly relevant.

Keywords: community organization, diaspora, Ukrainians, Ukrainian community, culture, Lithuania.

DOI https://doi.org/10.23856/4313

\section{Introduction}

With the events of 2014 winter, a large portion of the Ukrainian population chose to look for a safer place to live, with a lot of them looking towards the Baltics. In particular, the Baltic countries are a very popular direction of emigration. Every year the Ukrainian community in Lithuania grows. Foreign Ukrainians have an active life position, trying to preserve and promote their culture.

The topic of the activities of Ukrainians in the Baltic States is best covered in the Ukrainian research. The study of sociopolitical activities of Ukrainians starts from the beginning of the formation of community organizations in these countries, from the late 1980s. But mostly they are part of works about Ukrainians in the world, as examples in the work of researchers - Troshchinsky and Shevchenko. It is also important to understand the statistical data which were researched by our scholars, this subject was put in attention in the Ph.D. theses of geography scientist - Zubyk, and any others. An important source for the study of foreign Ukrainians is a review of the official websites of community organizations operating in Lithuania and Internet resources that cover the news of our diaspora. The source base of further research consists of 
testimonies of participants of community and cultural associations of Lithuania, reporting work of community organizations of these countries, and the World Congress of Ukrainians.

The purpose of the article is to show the community and cultural activities of the Ukrainian diaspora in Lithuania by conducting a systematic analysis of all available material.

\section{Organization of the Ukrainian community}

The Ukrainian national minority in Lithuania has quite deep historical roots. The first Ukrainian community centers were established in the country in the 1930s. In particular, the first Ukrainian community was officially registered in Lithuania in 1933. And in 1934, the cultural and educational society of Ukrainians in Lithuania was founded in Kaunas. However, at that time the part of ethnic Ukrainians in the country was not so significant. Some process of migration of ethnic Ukrainians to Lithuania was noticed only after the end of World War II, and then it was accelerated rapidly, a similar growth could be observed until 1989. From the late 1980s, Ukrainian community organizations in Lithuania became more prominent.

During this period, most countries in the post-Soviet space were characterized by a growing trend of activity of nationalist movements. Because at the time there were issues of restructuring the system and restoring independence. These issues were also relevant for Lithuania. A number of national minority societies were established in the country. Ukrainians were among the first who create their ethnic organization.

Thus, on December 8, 1988, the Community of Ukrainians of Vilnius was established at the Lithuanian Cultural Foundation, which was officially registered with the city administration on February 2, 1989. They saw their main goal in organizing Ukrainians in cultural and educational activities, concerts, debates, exhibitions, development of national cultural traditions, and preservation of the national consciousness of Ukrainians. The aim of the Community of Ukrainians of Vilnius was to unite Ukrainians from other Lithuanian cities. Thus, centers appeared in other cities: in Jonava, Klaipeda, Visaginas, Mazeikiai, and Kaunas.

In order to better coordinate the activities of all branches of Lithuania, it was decided to unite into one structure, so was formed - The Community of Ukrainians of Lithuania. Its creation was announced at the first constituent conference of the diaspora, which took place in Vilnius, October 28-29, 1989 (Vusyk, 2013: 8). At this conference was approved the confederate form of the Community activity. The council of representatives provided full autonomy and coordination to the parts of the community (Troshchynskyi, 1999: 295). As one of the main tasks of The Community of Ukrainians of Lithuania was the preservation and development of the Ukrainian ethnic group on the territory of Lithuania, the members of the Community established the first Ukrainian Sunday school in the Soviet Union outside the territory of Ukraine. It was located in Vilnius and started to work in the spring of 1989. The initiator of its creation and the first director was Oleksandr Avramenko, who united not only children but also adults. Later, Ukrainian Sunday schools appeared in Klaipeda, Visaginas, Jonava, and Mazeikiai. Initially, teachers worked on programs and textbooks from Canada and the United States, and only after the proclamation of Ukrainian independence - on textbooks from Ukraine.

\section{Ukrainian community after the Soviet Union period}

It should be noted, that during the period of the Soviet Union, the Ukrainian community had limited conditions for its development. But the situation began to change in the 1990s. 
Thus, after Lithuania gained independence, a new stage of development began for the Ukrainian community.

The independence of the Lithuanian Soviet Socialist Republic proclaimed on March 11, 1990, choosing the European path of development.

The Ukrainian community actively assisted the country in the struggle for independence, in particular during the January 1991 events in Vilnius. For active assistance to the Lithuanian people, some Ukrainians were awarded the «January 13» medal (Vusyk, 2013: 8).

Despite the fact that the Community focused on cultural and educational activities, its members actively expressed themselves in politics. They worked closely with the Lithuanian authorities. Representatives of the community were even members of some bodies of the Reform Movement of Lithuania.

In addition, our community in Lithuania was not averse to the situation in Ukraine. At that time, the community worked closely with the People's Movement of Ukraine, the Ukrainian Helsinki Union, Prosvita, the State Independence of Ukraine, the Lion Society, and others. Thanks to the community, numerous historical, religious, and nationalist publications were published, which at that time could not be published in Ukraine. The printing of the independent press, which was banned in Ukraine, was also organized.

After the initial issues were solved the Community of Ukrainians of Lithuania began work on the establishment of a religious center. In particular, Oleksander Avramenko found important information in archival sources. It turned out that during the Polish-Lithuanian-Teutonic War, Kostiantyn Ostrozky made a vow to build two churches in Vilnius. One of them was the Church of the Holy Trinity, built on the site of the wooden monastery of the same name. The Ukrainian church tradition in Lithuania is connected with this church. This information allowed the Community to start negotiations on the donation of this church for the restoration of the Ukrainian church. Thus, given the historical path of the Holy Trinity Church, on February 18,1991 , the religious community was registered as a «Catholic community of the Eastern Rite», and on July 4, 1991, the Vilnius City Council transferred the church building and bell tower to the religious community (Vusyk, 2013: 18).

At the same time, the community took care of amateur creative team's development in the country. Since September 1991, Tetyana Morhun has organized a children's ensemble of Ukrainian song and dance «Veselka» in the Vilnius club «Meteoras». This ensemble presented Ukrainian songs and dances on various stages of Lithuania and Ukraine. Subsequently, amateur Ukrainian groups began to form in other Lithuanian cities - Visaginas, Mazeikiai, and Jonava (Vusyk, 2013: 8).

The adoption of the Constitution of the Republic of Lithuania was an important stage not only for the country itself but also for our community. It took place more than two years after the country gained independence, namely, October 1, 1992. As in many other European countries, The Constitution of the Republic of Lithuania consists of a fundamental articles that protects the rights and freedoms of citizens (Troshchynskyi, 1999: 295). According to the constitution, before the law, the court, and other state institutions, all people are equal, regardless of race, nationality, language, origin, etc. In Article 29. It is important to note that any discrimination in the country is condemned, as referred to in Article 25 - «The freedom to express convictions and to impart information shall be incompatible with criminal actions - incitement to national, racial, religious, or social hatred, incitement to violence or to discrimination, as well as defamation and disinformation». Fundamental to our community is Article 37 of The Constitution of the Republic of Lithuania, which states that citizens who belong to national communities have the right to develop their language, culture, and customs. And Article 45, which states - «Ethnic 
communities of citizens shall independently manage the affairs of their ethnic culture, education, charity, and mutual assistance. Ethnic communities shall be provided support by the State» (Konstituciya...). That is, based on this, we see that the state has undertaken to promote the rights and freedoms of national minorities to preserve and develop their identity, as well as to support the activities of ethnic organizations, including Ukrainian.

It should be added that after the restoration of Lithuania's independence, almost all ethnic Ukrainians living in the country became citizens of the republic, they have the same rights and responsibilities as other citizens (Ukraintsi...). It is this remarkable fact that distinguishes the state of the Ukrainian diaspora in Lithuania, in comparison with other Baltic countries. Although it has certain disadvantages, as it affects the rapid assimilation of Ukrainians into Lithuanian society.

Later, other community organizations began to be established in the country, which actively carried out their activities, establishing Ukrainian-Lithuanian ties. In particular, some of Ukrainian community organizations included not only ethnic Ukrainians but ethnic Lithuanians. As an example - Aldona Vasiliauskiene, Head of the «Association of Lithuanian and Ukrainian historians». The Association held an international conference «Lithuania - Ukraine: History, Political Science, Cultural Studies» in Vilnius. Then organizations began to form in other cities of the country. Thus, the Ukrainian National Cultural Center «Barvinok» opened in Visaginas (Troshchynskyi, 1999: 296). But despite the activities of the community, it should be noted that there are some problems. For example, the crisis of Ukrainian school education in Lithuania, which is caused by the lack of modern methods and qualified teachers. More and more schools are closing. This, in turn, accelerates the assimilation of Ukrainians, who are increasingly beginning to consider themselves the bearers of only Lithuanian culture, rather than the culture of Ukrainians or Ukrainians in Lithuania, or Lithuanian-Ukrainian culture.

Another important achievement of the Ukrainian community in Lithuania is the unveiling of the monument to Taras Shevchenko in 2010. Also, every year the Community celebrates the memory of the poet, who lived for some time in Vilnius (Zvit..., 2005).

It was important for Ukraine that Lithuania recognize Holodomor as a carefully planned genocide of the Ukrainian people, which took place precisely due to the active educational work of the diaspora. This was stated in the statement of the Seimas of Lithuania of November 24, 2005 - «On honoring the victims of political repression and famine in Ukraine in 1932-1933» (IX Svitovyi..., 2008). Later, thanks to the educational work of the diaspora, the Holodomor was recognized as a genocide by other countries (Protokol..., 2008).

Lithuania pays close attention to the opinions of national minorities in the country and supports their initiatives. For example, during the V International Festival of Ukrainian Art and Information «Baltic Trembita», which took place in Vilnius, about 300.000 people had the opportunity to join the event through a television broadcast on Lithuania's first national television channel and national radio.

For many years, significant educational work has been going on in absolutely all Ukrainian organizations in Lithuania. Furthermore, thanks to special partnerships with community organizations in Trakai, Alytus, Siauliai, Druskininkai, and Basilionai, Ukrainian events are constantly taking place in these cities. In addition to ethnic Ukrainians, Lithuanians, Germans, Karaites, Greeks, Romanians, Russians, Latvians, and Estonians began to join the ranks of our community in Lithuania. Which join events taking place in the community. In particular, citizens of different nationalities took part in the actions that are dedicated to the Holodomor. As a great success - information support not only from the Lithuanians but also from the Belarusian 
and Russian communities of Lithuania, who used to be quite cautious about the Holodomor (Zvit..., 2007).

Representatives of the Ukrainian community have been repeatedly awarded honorary prizes. Victor Chernyshuk, Irena Petrulyonene, Natalia Shertvitene, received the medal of St. Vladimir the Great, the highest award of the World Congress of Ukrainians (Protokol..., 2008).

The following years were also marked by various important events for the community. In particular, the conference «Eugene Konovalets - a patriot of Ukraine, a citizen of Lithuania. 120 years since his birth». Which took place on June 17, 2011, in Vilnius. It was initiated by Lithuanian Ukrainians and co-organized by the Center for Liberation Movement Studies in Lviv. Among the nearly 60 participants were Ukrainian and Lithuanian scholars, former Lithuanian dissidents, journalists, representatives of Ukrainian and Lithuanian community organizations, and the Ukrainian community in Lithuania (X Svitovyi..., 2013).

Local Ukrainians are quite active in defending their political position and expressing their support for Ukraine. They organize protests and pickets, tell about the situation in their homeland. In particular, in November 2018, protests against the actions of Russian border guards in the Kerch Strait took place near the Russian Embassy in Vilnius. One of the protests was organized by the League of Young Conservatives, about 15 young people with Ukrainian and NATO flags chanted a slogan dedicated to Ukrainian heroes (U Vilniusi..., 2018).

It is important to note that in recent years the number of Ukrainians in Lithuania has started to increase. The Lithuanian Migration Department has released information according to which, as of the beginning of 2019, Ukrainians have become the largest foreign community in Lithuania, even ahead of Russians. According to information, there are almost $42 \%$ more Ukrainians living in Lithuania than in the previous years, which is about 17 thousand people. At the same time, the community of Russians in Lithuania is almost 12.5 thousand people (Ukraincy..., 2019). If we compare with the previous censuses - where we see that as of 2001 there were already 22.488 Ukrainians living in the country, and according to the 2011 census -16.423 people. In 2011 , the share of Ukrainians in the population of Lithuania was $0.6 \%$, the fifth largest ethnic group in the country (after Lithuanians, Belarusians, Poles, and Russians) (Zubyk, 2016: 82).

\section{Survey methodology and its results}

According to a survey I conducted on the social network Facebook, 136 respondents from Lithuania took part. $50 \%$ of respondents consider themselves carriers of a purely Ukrainian ethnic group. $25 \%$ identify themselves as Ukrainian-Lithuanian, $8.3 \%$ of Ukrainian-Russians and the same number of respondents consider themselves to be Russian-Lithuanian. Interestingly, none of the respondents identifies themselves with a purely Russian ethnic group.

It was also interesting that $83.3 \%$ of respondents see themselves living in Lithuania in 5 years. In other words, we can conclude from this that the majority of Ukrainians do not consider Lithuania as a platform for further emigration to other countries, such as the United States or Canada. So they want to stay in Lithuania, which shows their desire to integrate with the local ethnic group. However, only $38.9 \%$ stated that they wanted to obtain Lithuanian citizenship in the future and $47.2 \%$ answered that they did not want to obtain Lithuanian citizenship.

Very interesting situation with Ukrainian churches in Lithuania. Only 1 respondent answered that he goes to the Ukrainian church. If we touch on the issues of community organizations, $63.9 \%$ of respondents said they did not know Ukrainian organizations operating in Lithuania. $75 \%$ of respondents said they had no contact with the community at all. Neither 
Ukrainian nor Russian. Also, 63.9\% of Ukrainians do not attend events of Ukrainian organizations at all. 2.8\% regularly attend events of Ukrainian organizations, 33.3\% attend, but rarely.

Most of the respondents said that they learn about the community's activities from Facebook. And they believe that the community in Lithuania does not hold enough events. Therefore, $83.3 \%$ stated that they would like to take part in the events of the Ukrainian community, and $16.7 \%$ answered that they were not interested. All respondents, who have children answered that they have never attended Ukrainian-language schools.

Quite interesting that $-55.6 \%$ of respondents answered that they would stay in Lithuania even if there will be stable economic and political conditions in Ukraine, 38.9\% would return to Ukraine in that case, $5.6 \%$ would go to another country.

\section{Conclusions}

Thus, the Ukrainian community in Lithuania is quite active. Thanks to its activities, not only ethnic Ukrainians join the local community of Ukrainians, but also other residents of this country who are not indifferent to the fate of Ukraine. It should also be added that, unlike other Baltic countries, in the Republic of Lithuania after the restoration of independence, almost all Ukrainians that lived here at that moment received the citizenship of this state. This is one of the factors that influences the fact that Ukrainians quickly assimilate in Lithuania and often begin to consider themselves the bearers of purely Lithuanian culture, not Ukrainian. Another sad factor is the integration of local ethnic Ukrainians into the Russian diaspora. During the research, a survey was conducted, which gave an understanding of the current state of life of the Ukrainian community and will be a good ground for further analysis. This makes the study of the history and activities of the Ukrainian community in Lithuania extremely important and relevant.

\section{References}

Vusyk L. (2013). 25 rokiv Hromadi ukraintsiv Vilniusu [25 years of the Ukrainian Community of Vilnius]. Svoboda. Vydaie Ukrainskyi Narodnyi Soiuz. [in Ukrainian]

Zvit hromady ukraintsiv Lytvy (2005). [Report of the community of Ukrainians in Lithuania]. Richni zvity. Retrieved from: http://ukrainianworldcongress.org/UserFiles/File/Annual_Meetings_2005/Lithuania.pdf [in Ukrainian]

Zvit hromady ukraintsiv Lytvy (2007). [Report of the community of Ukrainians in Lithuania]. Richni zvity. Retrieved from: http://ukrainianworldcongress.org/UserFiles/File/Annual_Meetings_2007/Lithuania.pdf [in Ukrainian]

Zubyk A. I. (2016). Suchasna ukrainska diaspora: rozselennia, sotsio-demohrafichni protsesy: dys. kand. heohr. nauk: 11.00.02. [Modern Ukrainian diaspora: settlement, socio-demographic processes: dis. Cand. geogr. Science]. Lviv. [in Ukrainian]

Konstituciya Litovskoj Respubliki [The Constitution of the Republic of Lithuania]. Retrieved from: https://www.lrkt.lt/en/about-the-court/legal-information/the-constitution/192

Protokol IX Svitovoho Konhresu Ukraintsiv (2008). [Minutes of the IX World Congress of Ukrainians]. Kyiv. [in Ukrainian]

Troshchynskyi V. P., Shevchenko A. A. (1999). Ukraintsi v sviti. Ukraina kriz viky [Ukrainians in the world. Ukraine through the ages]. Kyiv: Alternatyvy. [in Ukrainian]

$U$ Vilniusi protestuiut proty ahresii RF u Kerchenskii prototsi (2018). [Vilnius protests against Russian aggression in the Kerch Strait]. UKRINFORM. Multymediina platforma inomovlennia 
Ukrainy. Retrieved from: https://www.ukrinform.ua/rubric-world/2588621-u-vilnusi-protestuut-proti-agresii-rf-u-kercenskij-protoci.html [in Ukrainian]

Ukraintsi u Lytvi. Posolstvo Ukrainy u Lytovskii Respublitsi [Ukrainians in Lithuania. Embassy of Ukraine in the Republic of Lithuania]. Retrieved from: https://lithuania.mfa.gov.ua/ua/ ukraine-it/ukrainians-in-lt [in Ukrainian]

Ukraincy stali krupnejshej inostrannoj obshinoj v Litve (2019). [Ukrainians have become the largest foreign community in Lithuania]. Informacionnoe agestvo: Interfaks-Ukraina. Retrieved from: https://interfax.com.ua/news/general/559995.html. [in Russian]

IX Svitovyi Konhres Ukraintsiv 20-22 serpnia (2008). [IX Ukrainian World Congress August 20-22]. Kyiv. [in Ukrainian]

X Svitovyi Konhres Ukraintsiv (2013). [X Ukrainian World Congress]. Lviv. [in Ukrainian] 